Monitoring directions and rates of change in trees outside forests through multitemporal analysis of map sequences ${ }^{1}$

Tobias Plieninger ${ }^{\mathrm{a}, \mathrm{b}, *}$

${ }^{a}$ Berlin-Brandenburg Academy of Sciences and Humanities, Ecosystem Services Research Group, Jägerstr. 22/23, 10117 Berlin, Germany

${ }^{\mathrm{b}}$ Humboldt-Universität zu Berlin, Geography Department, Unter den Linden 6, 10099 Berlin, Germany

* Corresponding author. Phone: +49-30-20370-538, Fax: +49-30-20370-214, E-mail address: plieninger@bbaw.de (T. Plieninger).

\footnotetext{
${ }^{1}$ Postprint. Published Version: Plieninger, T. (2012): Monitoring directions and rates of change in trees outside forests through multitemporal analysis of map sequences. Applied Geography 32: 566-576. 


\title{
Monitoring directions and rates of change in trees outside forests through multitemporal analysis of map sequences
}

\begin{abstract}
This study explores the potential of historical maps to detect, measure and monitor changes of trees outside forests. The main goal is to assess local-level changes of scattered trees and orchards and their land-use determinants in two areas in Southern Germany between 1901/1905 and 2009. Firstly, overall landscape changes are recorded. Secondly, the spatialtemporal trajectories of scattered trees and their land-use determinants are identified. Thirdly, changes in quantity and fragmentation patterns of traditional orchards are analyzed in their relationship to overall land-cover change. The results confirm major losses in scattered trees, mainly due to urbanization, agricultural intensification, and land abandonment. They further reveal that, while orchards have persisted in total area, they have undergone critical changes towards a simplified landscape structure and loss of the traditional land-use mosaic, which is a characterizing feature of high nature value landscapes. Multi-temporal assessment showed that most trends have been continuous and did not change directions over time, but rather accelerated during periods of rapid change (most dramatically in the $1950-1990$ period). The case of orchards and scattered trees illustrates a major problem of cultural landscapes in Europe: Semi-natural landscape features of high nature value are threatened by both intensification and abandonment of land uses. This makes their conservation a potentially costly enterprise, as both opportunity costs for lost alternative land uses and for conservation management costs arise.
\end{abstract}

\section{Keywords}

Agricultural landscape, Driving forces, Ecosystem services, GIS, Landscape dynamics, Swabian Alb 


\section{Introduction}

Over the course of the $20^{\text {th }}$ century, central European cultural landscapes have experienced pivotal transformations, both in terms of landscape composition and spatial configuration (Feranec et al., 2010; Vos \& Klijn, 2000). To understand the underlying drivers and processes of landscape change and to inform policy and planning instruments to respond to these changes, the determination of directions and rates of landscape change is essential (CalvoIglesias et al., 2006). However, rates of change have only recently come to the fore of landscape research (Schneeberger et al., 2007), and most ecological studies have analyzed only bi-temporal landscape changes (Gillanders et al., 2008). Particularly understudied are the multitemporal trajectories of so-called 'trees outside forests' (FAO, 2000). In the central European setting, these comprise (a) a diversity of individual scattered trees and shrubs (hedgerows, tree rows, woodlots, copses, isolated trees and tree groups etc.) and (b) formal agroforestry systems (mainly orchards).

Scattered trees are composed of usually native or naturalized woody species, intermingled into croplands, grasslands, and wastelands. In the landscape they are spatially arranged either as point (e.g. isolated trees), line (hedgerows, alleys, riparian buffers), or clustered (e.g. woodlots, tree groups) features (Plieninger, 2011). Orchards represent a land-use system composed of open stands of standard fruit trees within gardens, meadows, or crop fields. The most common fruit trees are apple, pear, plum, and sweet cherry, planted at a density of 20 100 stems per ha. As a general feature, the trees have a minimum stem height of $160 \mathrm{~cm}$ to allow for sound utilization of the ground below tree canopies (Eichhorn et al., 2006). This region-specific and traditional type of orchard is spread across 11 central European countries, with a total of about 1 million hectares (Herzog, 1998).

Both scattered trees and orchards have become appreciated as a source of biodiversity and ecosystem services, both in agricultural (Manning et al., 2006) and urban landscapes (Jim \& Chen, 2009). Many are of considerable habitat-conservation value, as they represent patches of native or semi-natural habitat within an agricultural matrix. They offer food resources (particularly winter food supplies), nesting areas, and physical protection for many animal species (Freemark et al., 2002; Hinsley \& Bellamy, 2000). Moreover they are able to provide connectivity between forests, woodlands, and other semi-natural habitats that is often critically important to sustaining metapopulations of wildlife (Grashof-Bokdam et al., 2009). Outstanding ecosystem services comprise climate regulation (e.g. through carbon sequestration), water regulation (through flood control), erosion control and water purification (through filtering biocides, fertilizers, and sediments out of agricultural runoff) (Plieninger, 2011). Cultural services of landscapes can be greatly enhanced by scattered trees and orchards in terms of inspiration, aesthetics, sense of place, recreation and tourism (Weller, 1996). Trees outside forests are important carriers of land-use legacies and witnesses of landscape history, as they relate to past land-use patterns and processes (Clare \& Bunce, 2006; Skaloš \& Engstová, 2010).

Study of the change trajectories of orchards and scattered trees is important due to the ecosystem services that they provide and their presumed worldwide degradation (Fischer et al., 2010; Plieninger et al., 2010). However, common patterns of severe reduction of scattered 
trees have been described only qualitatively (Eichhorn et al., 2006). Existing quantitative analyses of certain types of trees and woodlands outside forests (e.g. hedgerows or silvopastures) mostly refer to the time from the 1950s onwards, when aerial photographs and satellite imagery became available (Kristensen \& Caspersen, 2002; Plieninger \& Schaar, 2008). Neglect of the study of long-term dynamics, however, runs the risk of missing potentially decisive periods of tree gain or loss. Only a few studies have mapped and quantified scattered tree trajectories at a regional scale and these only for specific elements within the definition of trees outside forests (Deckers et al., 2005; Skaloš \& Engstová, 2010).

The only spatially explicit sources reaching back in time farther than the past 50 years are topographic maps (Bender et al., 2005), which additionally offer the opportunity to acquire repeated measurement of the same area on a regular basis (Vuorela et al., 2002). In the present study, I consider the advantage of historical maps to detect, measure and monitor changes of trees outside forests. The main goal is to assess local-level changes of orchards and scattered trees and their land-use determinants in two selected areas of Southern Germany between 1901/1905 and 2009. Firstly, overall land-cover changes are recorded. Secondly, the spatialtemporal trajectories of scattered trees and their land-use determinants are identified. Thirdly, changes in quantity and fragmentation patterns of traditional orchards are analyzed in their relationship to overall land-cover change. The information generated in this study will be a useful basis for analyzing underlying drivers of change and designing appropriate conservation and restoration strategies.

\section{Material and methods}

\subsection{Study areas}

The Swabian Alb in southern Germany $\left(48^{\circ} 24^{\prime} \mathrm{N}, 9^{\circ} 12^{\prime} \mathrm{E}\right)$ is a low mountain range (highest peak: 1,015 m asl) that was declared a UNESCO Biosphere Reserve in 2007 (Fig. 1). It is of jurassic origin and expands across a distance of approximately $200 \mathrm{~km}$ from the Southwest to the Northeast. Climate is temperate, with average annual temperatures between 4 and $7^{\circ} \mathrm{C}$ and up to $1,000 \mathrm{~mm}$ of annual precipitation. A geographic elevation up to $400 \mathrm{~m}$ in height - the Alb Escarpment - runs along the entire Northwestern border and divides the area into a foothill area and a plateau area. Due to its proximity to the Stuttgart metropolitan region, the foothills are at the rural-urban interface, they are densely populated and main economic centers. This area exhibits steep river valleys whose slopes are mainly used for fruit-growing. The plateau is more remote and characterized by relatively harsh climate and soil conditions and lower population densities.

Taking the diversity of regionally available scattered trees and orchards into account, two municipalities were chosen as study areas. In the context of a larger interdisciplinary research project on ecosystem services in cultural landscapes (http://www.ecosystemservices.de) Unterlenningen and Zainingen had been identified as representative communities for foothills and plateau in terms of ecological properties, prevailing land-uses, demography, and socioeconomic characteristics. The Unterlenningen area is mainly located in the foothills, which harbour the largest contiguous orchards in Europe (Fig. 2a). The other area, Zainingen, lies on the northwestern plateau of the Swabian Alb. Hedgerows, shrublands, isolated trees, tree groups, and alleys are commonly intermingled into grasslands and croplands there (Fig. 2b 
and 2c). This plateau area will be used to specifically assess the trajectories of individual scattered trees. Many of its prevalent configurations of scattered trees (hedgerows, woodlots, etc.) are protected by state conservation law, but in contrast to Unterlenningen it does not contain any orchards.

\subsection{Data sources}

The basis for this landscape analysis were sets of standardized topographic maps at 1:25,000 scale (dates: 1905, 1930, 1955, 1967, 1979, 1989, 1998, 2009 for Unterlenningen; 1901, 1910, 1923, 1932, 1958, 1966, 1979, 1989, 1999, 2009 for Zainingen). The oldest maps created using modern survey methods dated from 1901 and 1905, which determined the starting time period. Earlier maps usually do not allow the analysis of landscape microstructure due to spatial errors and inconsistent symbologies (Skaloš et al., 2011). The topographic maps were created by the Württemberg State Statistical Office and are today published by the Baden-Württemberg Land Survey Administration. Specified dates refer to the year that the respective map was published. To increase accuracy, the study area was limited to those parts of the communities that were contained within one map sheet. The extent of these study areas is 982 ha (Unterlenningen, map sheet 7422) and 1,228 ha (Zainingen, map sheet 7523). Scanned maps were obtained from the Baden-Württemberg Land Survey Administration and the Württemberg State Library and georectified in ArcGIS 9.3. Root mean squared errors were between 1.5 and $4.8 \mathrm{~m}$ (mean: $3.3 \mathrm{~m}$ ). The division of map sheets and the use of Gauss-Krüger coordinates were uniform throughout the time sequences. The symbologies of the maps were largely consistent. Maps from 1901, 1905 and 1910 did not exhibit an explicit legend, but the symbols used were identical to those of subsequent maps. Symbologies were slightly changed between 1979 and 1989: 'Grazing lands were taken out of 'wastelands' and integrated into 'grasslands' (which had little influence in the study areas, as wasteland area was small both in 1979 and 1989), and scattered trees were not distinguished any more into 'fruit trees' and 'forest trees' (therefore this distinction was not taken on in the study). The map-based analysis was interpreted through ancillary sources of historical ecology (Egan \& Howell, 2001), including agricultural statistics, observational field evidence, local literature on landscape history, and three interviews with local experts on conservation and land-use history.

\subsection{Land-cover and tree classes}

For each area, vector GIS models were built-up in which data of two types were recorded: land-cover classes (polygon features) as reflection of the biophysical state of the real landscape (Feranec et al., 2010) and scattered trees (point features). For each period, a total of eight broad land-cover classes were digitized manually on the basis of map symbologies: Forest, urban, cropland, wasteland, orchard, grassland, vineyard/hops, and quarry. The 'wasteland' category was the most heterogeneous and included heathlands, shrublands, unproductive lands, and (until 1979) grazing lands. Separate layers were created for each time step, beginning with 2009 and working backwards to the earlier layers. The area of each land cover class was analyzed from the digitized maps with ArcGIS and calculated in percent of the study area. The uniform 'single tree' label used in map symbologies for scattered trees was used to depict individual trees, tree groups, alleys, tree rows, hedgerows, and copses. The 
resulting maps represent both land cover and the spatial structure of scattered trees for each time step and study area.

\subsection{Scattered tree analysis}

The evolution of scattered tree abundance over time was standardized into figures of trees per $\mathrm{km}^{2}$. These were converted into raster data (plot size: $1 \mathrm{ha}$ ) to account for presence or absence of tree-covered land. As scattered trees may be represented with different degrees of accuracy on the maps, monitoring absence/presence on the 1 ha plots has been assumed to be more reliable than counting individual trees. Doing so helps to distinguish actual change from interpretation errors: for example, if a shrubland has been symbolized by two trees in an older map, but by only one tree in a more recent map. General accuracies for the generated 1 ha plots were evaluated for the 2009 layer by comparing the mapped data to the presence of scattered trees as found for the same location in high-resolution orthophotographs from 2008. All plots not covered by cropland, grassland or wasteland were included in the accuracy assessment, resulting in 178 reference plots for the foothill and 971 reference plots for the plateau area. Overall agreement of the classification with the data obtained from orthophotos was $70.8 \%$ for the foothill and $85.9 \%$ for the plateau area. On $6.7 \%$ (foothills) and $2.1 \%$ (plateau) of the reference plots, map-based analysis had classified scattered trees although aerial photography showed that there weren't any. On $22.5 \%$ (foothill) and $12.0 \%$ (plateau) of the reference plots, map detection had suggested that plots were tree-less although detailed analysis of orthophotographs actually found scattered trees. All in all, the number of plots containing scattered trees was $68.3 \%$ (foothills) and $78.9 \%$ (plateau) higher than estimated from the maps.

When more than four trees were exhibited in a linear form (particularly along roads), they were additionally sampled and displayed as linear features (alley/tree row). The relationships between the abundance of scattered tree plots (and alleys/tree rows) with the extent of important land-cover classes over time $(n=10)$ were analyzed using Spearman's rank correlation. All scattered trees plots in the 1901 Zainingen map in the test were included $(n=291)$. A nonparametric Mann-Whitney $U$ test was applied to compare spatial patterns of scattered trees that were lost from 1901-2009 in the plateau area with those that persisted. An array of continuous parameters was used as independent variables (increase/decrease of grassland, wasteland, cropland, forests, and built-up land in the respective 1 ha-plots from 1901-2009). Here the aim was to relate loss or persistence of scattered trees to overall landuse changes such as agricultural intensification, agricultural extensification, and urbanization. Differences of $\mathrm{p}<0.05$ are taken as significant.

\subsection{Orchard analysis}

In addition to the calculation of orchard cover change over time, changes in the spatial pattern of orchards were quantified through standard landscape metrics at class level (mean patch size, patch density, mean patch distance, largest patch index, total and relative adjacency index) to allow for the detection of temporal patterns of landscape change (Haines-Young \& Chopping, 1996). The development of orchard fragmentation over time was assessed using morphological spatial pattern analysis (Ostapowicz et al., 2008) that categorizes orchard pixels (size: $10 \mathrm{~m} \times 10 \mathrm{~m}$ ) based on their proportion and connectivity within a moving 
window. Land cover from each map was overlaid, and the corresponding change from one land-cover class to another was derived for each patch. Based on this information, crosstabulation of land-cover classes between the 1905 and 2009 period revealed the most important sources of gain or loss of orchards. Observed transition rates (based on area values) were contrasted to those rates that would be expected from a random transition (Pontius et al., 2004). Only transitions where observed rates were larger than expected rates were considered as systematic transitions. A map of persistence and changes of orchard distribution was built up by adding binary change/no change maps for the whole study period.

\section{Results}

\subsection{Changes in land cover}

In the foothill area, orchard was the dominant land cover across all periods from 1901 to 2009, whereas in the plateau area it was arable land (Fig. 3 and 4). Both land-cover types remained relatively stable over time. Forest cover increased only moderately $(15 \%)$ in the foothills, but grew by $74 \%$ on the plateau area. In both areas, the area covered by built-up land increased heavily, reaching $305 \%-310 \%$ of their $1901 / 1905$ extent by 2009 . Also, there was a strong decline in the area of grassland (42\% and $46 \%)$ and wasteland $(45 \%$ and $71 \%)$ in both areas. In the foothills area, vineyards and hops plantations were created at the end of the $19^{\text {th }}$ and the beginning of the $20^{\text {th }}$ century, but were completely abandoned between 1905 and 1930. Both areas underwent the most important area changes after the 1950s (in particular loss of cropland and expansion of urban areas in the foothills) and 1960s (in particular loss of grassland and expansion of forest and urban areas in the plateau), although all periods exhibited land-cover dynamics. Change trajectories were relatively continuous and unidirectional.

\subsection{Frequency changes, patterns, and trajectories of scattered trees}

The numbers of plots with trees scattered across farmland, grassland, and wasteland were in strong decline in the foothills (73\%) and on the plateau (58\%) from 1901 to 2009 (Fig. 5). The strongest losses were experienced by alleys and tree rows. The greatest decreases occurred in the 1980s for scattered trees and in the 1970s for alleys and tree rows. In the plateau area, the prevalent trajectory for scattered trees (66\% of plots) is a loss of trees from 1901-2009, concentrated in areas close to settlements, traffic infrastructure, and forests (Fig. 6). Only $16 \%$ of plots were persistently covered by scattered trees, while $19 \%$ of plots represented newly established plots of scattered trees, mostly on arable land.

The results of correlations over 10 time layers show that the decrease of scattered trees on the plateau area was significantly associated with forest expansion, increase of built-up land, and the decrease of wastelands and grasslands (Table 1). For alleys and tree rows, these temporal associations were even stronger. Nonparametric testing of the spatial associations of 291 plots covered by scattered trees in 1901 drew a similar picture: Grassland decline, increase of forests, and increase of built-up land were much stronger on plots where trees had been lost compared to plots with persistent scattered trees (Table 2). However, no significant difference was found for the decrease of wastelands and croplands.

\subsection{Area changes, patterns, and trajectories of orchards}


Orchard area increased in the foothills by $16 \%$ from 1905 to 2009 . Orchard fragmentation analysis showed that mean patch size of orchards strongly increased over time (19.4 ha in $1905 ; 72.0$ ha in 2009), while density decreased from 1.6 to 0.5 patches per $\mathrm{km}^{2}$ within the same period. By 2009, 59.6\% of orchard area was within one large patch. Mean distance between patch edges increased from $39.0 \mathrm{~m}$ to $44.2 \mathrm{~m}$. Morphological spatial pattern analysis confirmed a continuous process of defragmentation (Table 3). The proportion of core orchards increased from $73 \%$ to $89 \%$ between 1905 and 2009 . During the same time, the share of edges, islets, and other fragmented types of orchards decreased from $27 \%$ to $11 \%$. Connectivity between core orchards through so-called bridges declined from $1 \%$ to $0 \%$.

Five major orchard change trajectories were identified through overlay of eight temporal layers of orchard areas from 1905 to 2009: (A) areas of long-term persistence (275 ha), (B) increasing orchard cover (57 ha), (C) decreasing orchard cover (104 ha), (D) turnover (areas that showed two or more changes across the seven periods analyzed) with orchard in 2009 (29 ha), and (E) turnover without orchard cover in 2009 (20 ha). Loss areas are mainly concentrated on the surroundings of settlement areas, while areas of increasing orchard cover are distributed across the outskirts of the municipality (Fig. 7). Type E is also concentrated in the vicinity of urban areas, while type $\mathrm{D}$ is frequently close to type $\mathrm{A}$ and $\mathrm{B}$.

Orchards experienced both progressive gains and losses in area between 1905 and 2009, with gains (113 ha) being larger than losses (70 ha). Three systematic sources of gain to orchards from 1905 to 2009 were found: the abandonment of croplands (67 ha), vineyards and hops plantations (26 ha), and wastelands (16 ha) (Table 4). Systematic losses were due to conversion into urban areas (43 ha) and forest expansion (9 ha). Vineyard conversion was limited to the 1905-1930 period, whereas croplands and wastelands were converted continuously over almost all periods. The largest absolute orchard losses were experienced in the 1955-1967 (37 ha) and the 1967-1979 (35 ha) periods, largely due to conversion into urban areas. The biggest gains (72 ha) were found from 1955 to 1967 (mainly through conversion of croplands), but also in the 1905-1930 period (41 ha, with conversion of vineyards and hops plantations being the most important process) and in the 1979-1989 period (43 ha, with cropland abandonment being the major force). During the last studied decade, both loss and gain rates became smaller. The absolute adjacency index of orchards decreased by $56 \%$ from 1905 to 2009 , due to the overall decrease of orchard edges. Most orchards were adjacent to cropland, forest, vineyards, and hops plantations in 1905. In 2009, cropland and forests still shared most edges with orchards, but urban areas had increased enormously in adjacency, from $4 \%$ to $20 \%$ (Table 5).

\section{Discussion}

\subsection{Directions and rates of landscape change}

This study examines the dynamics of small woody landscape elements in the context of overall land-cover change in a temperate area of Europe (most previous studies of scattered trees focused on Mediterranean Europe, for example Costa et al., 2009). The trajectories of individual scattered trees in the study area corresponded to patterns of uniform decline during the second half of the $20^{\text {th }}$ century particularly exhibited by hedgerows in other European cultural landscapes (Burel \& Baudry, 1990; Deckers et al., 2005; Petit et al., 2003). The most 
conspicuous development in the study area is that alleys have vanished almost completely from the landscape. Most of these alleys had been planted with fruit trees, ashes, maples, rowan, whitebeam and other tree species between 1780 and 1850 for the provision of fruit, firewood, and shade for pedestrians and draft animals. During interviews, local experts emphasized that during the studied period few efforts were made to replant a following cohort of saplings, as society no longer appreciated the benefits of alleys. Further declines were caused by clearing in the course of road enlargements, straightenings, and other construction works and also due to concerns for road safety. Besides alleys, many individual fruit trees and hedgerows were also lost in the area (Ressel \& Zimmerer, 1989). Both temporal and spatial analysis showed significant congruencies of the retrogression of scattered trees with (a) expansion of built-up land (that affected alleys and fruit trees around settlements), (b) forest increase (which replaced hedgerows and shrublands through natural succession and afforestation, mainly with spruce) and (c) decrease of once tree-covered wastelands and grasslands. However, the present study also reveals certain gains in scattered trees that could partly compensate for losses. Interviewees stressed that hedgerows and copses of blackthorn, dog rose, hawthorn, and other shrub species had established themselves spontaneously by succession along the edges of fields and roads, on clearance mounds, and other sites where crop cultivation or sheep husbandry had once been more intensive than today. The 'swapping' of gains and losses is typical for scattered trees in linear or small-scale structures, the dynamics of which are significantly influenced by changing land uses in adjacent areas (Sklenicka et al., 2009).

In contrast to the national trend in Germany (Eichhorn et al., 2006; MLR, 2009), orchard area in the study site was locally persistent and even increased slightly from 1905-2009. Analysis of systematic landscape transitions allowed the linking of patterns of orchard gain and loss to underlying processes of landscape change (Pontius et al., 2004). Systematic gains were due to the abandonment of crop cultivation, viniculture, and hops plantation. These findings were confirmed by local experts, who ascribed the increase of orchards in the foothills to the abandonment of vineyards as a consequence of an invasion of grape phylloxera and of arising competition with wine production from the Rhine area from the end of the $19^{\text {th }}$ century onwards. Later, fruit trees were planted on fields, as orchards are far less labor-intensive than arable crops and can be managed by part-time farming (Mailänder, 2005). Losses were caused both by intensified (urbanization) and extensified (conversion into forests) land-uses. Adjacency analysis (Table 5) showed that village edges increasingly connect to orchards, which makes them even more vulnerable to land development in the future. Conversion to forest indicates that many orchards have been partly or fully abandoned due to lack of profitability. Local experts confirmed that many fruit trees are overaged, lack regeneration, and are overly neglected in the remaining orchards. This 'extinction debt' (Kuussaari et al., 2009) may accelerate future losses of orchards, as the survival of aged fruit trees over many years conceals that stands are committed to extinction without tree regeneration. However, changes in the spatial arrangement of orchards were much stronger than their overall area changes. All indicators used point to a sustained spatial defragmentation; by 2009, the remaining orchards were concentrated in just four large patches. On the one hand, this trend towards larger units of land cover may increase habitat suitability for disturbance-sensitive animal species. On the other hand, it can be understood as a large-scale simplification of 
landscape structure (Geri et al., 2010; Persson et al., 2010). The strongly reduced length of total orchard edge indicates that the amount of ecotones (which are regarded as the most valuable habitats in cultural landscapes; von Schnakenburg \& Schmieder, 2007) - has strongly decreased. By dissolving away from the traditional land-use mosaic of meadows, pastures, arable land, hops plantations, and heathlands, orchards in the study area have followed the trend of agricultural upscaling (facilitated by land-consolidation projects and by concentration processes in agriculture). However, there are no studies yet that relate the simplification of orchard structure to richness and composition of animal and plant species.

The analysis of between eight and ten time sequences allowed a more differentiated insight into the periods in which important landscape changes took places. It has to be taken into account, however, that land-use changes may take several years until they become visible as land-cover changes on a map, especially when monitoring slow-growing landscape elements such as scattered trees (Plieninger $\&$ Schaar, 2008). In the first half of the $20^{\text {th }}$ century, during which small-sized family farms dominated and agricultural systems relied mostly on local natural and human resources as human inputs, the abandonment of vineyards and hops plantations - incidentally demonstrating that land-use extensification and land abandonment are not always recent processes - and the expansion of orchards were important processes in the foothill area, while there were few changes on the plateau. The period from the 1950s onwards, an era of rapid economic development, implied severe pushes of urbanization in the foothills and plateau area. Population grew by $43 \%$ in the foothills and by $29 \%$ on the plateau from 1950 to 2009 (StLA, 2011). In the foothills, farmlands were abandoned when crop cultivation became unprofitable and alternative jobs to farming developed in manufacturing and trade (von Schnakenburg \& Schmieder, 2007). On the plateau, grasslands and wastelands (especially traditional juniper heaths) were converted into forests through afforestation and natural succession as a consequence of the decline of sheep pastoralism (Bender et al., 2005; Poschlod \& WallisDeVries, 2002). Intensification, specialization, and concentration of agricultural production culminated in this period, and the simplification of landscape structures was strongest. This becomes visible through the increase of farm sizes from 8 ha to 26 ha (foothills) and from 11 ha to 60 ha (plateau) between 1979 and 2007, as documented in agricultural statistics. At the same time, the total number of agricultural operations decreased from 143 to 47 farms (foothills) and from 239 to 51 farms (plateau) (StLA, 2011). Losses of scattered trees were particularly high. Since 1990, land-conversion trends have slowed down, the extent of scattered trees has stabilized and alleys have even increased slightly (possibly in consequence of a post-productivist transition of agriculture; Mather et al., 2006). Public awareness concerning cultural landscapes has been growing, translating into stricter conservation legislation (such as the 1992 Baden-Württemberg State Conservation Act) and publicly funded landscape-management efforts (for example, replanting of alley trees along roads). Although change was immanent throughout all sequences studied, the magnitude of transformations indeed accelerated greatly after the 1950s, as stated by Antrop (2005). The present study also confirms findings from Switzerland that transformation rates peaked in the 1960s and 1970s and have since slowed down due to saturation and other effects (Schneeberger et al., 2007).

\subsection{Limitations of the method}


The method developed in this study has allowed discernment of trajectories of scattered trees and orchards and to relate them to overall landscape changes. However, when interpreting landscape changes, it needs to be considered that delineating isolated trees in agricultural landscapes is 'currently more a matter of judgment (interpretation) than based on strict rules' (van Doorn \& Pinto Correia, 2007, p. 170). Another problem is that no detailed classification system is currently available for trees outside forests (Skaloš \& Engstová, 2010). This is a major drawback, as small woodlots, isolated trees, hedgerows, shrublands, and the like may exhibit diverging change trajectories and ecological functions. While orchards have clearly delimited boundaries and are thus easy to distinguish from other land-cover classes, it is a challenging task to trace scattered trees reliably over time (Vuorela et al., 2002). For the present study, consistency was achieved by evaluating only sets of 1:25,000 basic maps. These maps were manufactured on the basis of the Württemberg Land Survey, which had been started in 1918 with the aim of creating reliable information for taxation. Although survey methods improved over time, in particular with the rise of photogrammetric methods, they have been characterized by a consistent historical development with relatively homogeneous projection, scale, symbolization, purpose and generalization over time (LVA Baden-Württemberg, 1993). Mean errors below $5 \mathrm{~m}$ justifies the use of all map sequences. However, there may be inconsistencies in the generalization of scattered trees. Therefore, the analysis of scattered tree trajectories was not based on individual tree symbols, but rather on 1 ha-plots in which all documented scattered trees were pooled. A simple validation assessment for the 2009 data showed that such map-based assessment of scattered tree plots reaches an accuracy between $71 \%$ and $86 \%$. Topographic map-based assessment strongly underestimates actual numbers of scattered trees, as arrangements of trees (for example, tree groups or hedgerows) are reduced into one tree symbol. Development of more accurate rule-based, automatic detection of trees outside forests through modern remote sensing, GIS tools and high resolution imagery is underway (Sheeren et al., 2009), but is limited to the time spans for which aerial photographs and satellite imagery are available. The selection of sequences of topographic maps offered the advantage of being able to assess an elevated number of time steps, although the First and Second World Wars interrupted the edition of updated maps and the method allowed insights only from the beginning of the $20^{\text {th }}$ century onwards. Moreover, topographic map-based analysis does not give insight into qualitative changes of orchards and scattered trees, such as about tree species, vegetation structure, or age distribution. Although these shortcomings need to be considered when interpreting the results, the method was successful in accounting for the major changes of trees outside forests over an extended period of time.

\section{Conclusion}

This study demonstrates that fine-scale spatial dynamics of small landscape elements can be much more intense than changes at the larger scale of coarse land-cover classes. In-depth analysis of small-scale landscape changes are important complements to global-scale land change analyses, as many land-use decisions are taken at the local and regional scales (Käyhkö et al., 2011; Siren \& Brondizio, 2009). The systematic assessment of sequences of topographic maps has proven valuable for the detection of otherwise overlooked changes in trees outside forests as well as for the analysis of relationships between tree abundance and overall land-cover changes. However, a more meaningful interpretation of maps requires 
additional contextual information from written or oral sources. One important finding was that scattered trees suffered major losses in the study area as a consequence of agricultural intensification, urbanization and abandonment of land uses. Orchards have not undergone these area losses, but do carry a 'regeneration debt' that may lead to area losses in the near future. Moreover, orchards have experienced critical changes from complex towards simplified landscape structures and loss of their traditional high nature value land-use mosaic. Multi-temporal assessment showed that most trends have been continuous and have not changed direction over time, but did accelerate during periods of rapid change, especially from 1950 to 1990. Though difficult to quantify, the long-term dynamics of trees are particularly relevant, as trees provide ecosystem services to a much larger degree than their extent would suggest.

These findings offer important insights for the planning and management of multifunctional agricultural landscapes, as orchards and scattered trees illustrate a major problem of cultural landscapes in Europe: Semi-natural landscape features of high nature value are little resilient against both intensification and abandonment of land uses and, therefore, require sustained human intervention (Jones et al., 2011). For example, orchards depend on regular grass mowing, pruning, and replanting; alleys on pruning and renewal; hedgerows on regular coppicing. This makes their conservation a potentially costly enterprise, as both opportunity costs for forfeited alternative land uses and production costs for conservation management arise. Nature conservation management may amount up to $250 €$ per ha and year (orchards) or $510 €$ per ha and year (hedgerows) (Schleyer \& Plieninger, 2011). Classical conservation approaches have aimed at putting trees outside forests via nature conservation legislation. The fact that the number of scattered trees has stabilized since the 1990s may be indeed considered as a success of state protection of these landscape structures (introduced in 1992). However, regulatory approaches can only stop outright destruction of trees, but are unable to safeguard the sustained management that is necessary for their long-term survival. Market-based approaches to conservation of biodiversity and ecosystem services have been implemented both by the state and by private actors. They may have contributed to a slowdown of scattered tree regression since the 1990s, but are far from the financial scale that would be needed to manage high nature value land comprehensively (Hampicke, 2006). Therefore, it will be necessary to focus restoration efforts toward innovative, low-cost forms of scattered tree management that maintain biodiversity and ecosystem services. However, regionalized systems, such as the orchards of the foothill area, cannot be preserved in their diversity of land uses based on standardized financial payments alone. Rather, it is of paramount importance to revitalize local ecological knowledge and the voluntary commitment of hobby farmers, gardeners, conservationists, and other citizens for the stewardship of scattered trees as important component of cultural landscapes.

\section{Acknowledgement}

Support for this research was obtained from the Social-Ecological Research Program of the German Federal Ministry of Education and Research (FKZ 01UU0904A). The funding source was not involved in the study design; the collection, analysis and interpretation of data; the writing of the report; or in the decision to submit the paper to this journal. Maps were provided by the Landesamt für Geoinformation und Landentwicklung Baden-Württemberg 
(Az. 2851.9-1/19). Thanasis Kizos, Christian Schleyer and Chris Hank improved an earlier version of the manuscript. Stephan Kroel and Martin Mantel worked on data acquisition and

digitalization of land-cover data.

\section{References}

Antrop, M. (2005). Why landscapes of the past are important for the future. Landscape and Urban Planning, 70 (1-2), 21-34.

Bender, O., Boehmer, H. J., Jens, D., \& Schumacher, K. P. (2005). Using GIS to analyse long-term cultural landscape change in Southern Germany. Landscape and Urban Planning, 70 (1-2), 111-125.

Burel, F., \& Baudry, J. (1990). Structural dynamic of a hedgerow network landscape in Brittany, France. Landscape Ecology, 4 (4), 197-210.

Calvo-Iglesias, M. S., Fra-Paleo, U., Crecente-Maseda, R., \& Diaz-Varela, R. A. (2006). Directions of change in land cover and landscape patterns from 1957 to 2000 in agricultural landscapes in NW Spain. Environmental Management, 38 (6), 921-933.

Clare, T., \& Bunce, R. G. H. (2006). The potential for using trees to help define historic landscape zones: a case study in the English Lake District. Landscape and Urban Planning, 74 (1), 34-45.

Costa, A., Pereira, H., \& Madeira, M. (2009). Landscape dynamics in endangered cork oak woodlands in Southwestern Portugal (1958-2005). Agroforestry Systems, 77 (2), 8396.

Deckers, B., Kerselaers, E., Gulinck, H., Muys, B., \& Hermy, M. (2005). Long-term spatiotemporal dynamics of a hedgerow network landscape in Flanders, Belgium. Environmental Conservation, 32 (1), 20-29.

Egan, D., \& Howell, E. A. (2001). The Historical Ecology Handbook. Island Press, Washington D.C.

Eichhorn, M. P., Paris, P., Herzog, F., Incoll, L. D., Liagre, F., Mantzanas, K., Mayus, M., Moreno, G., Papanastasis, V. P., Pilbeam, D. J., Pisanelli, A., \& Dupraz, C. (2006). Silvoarable systems in europe - past, present and future prospects. Agroforestry Systems, 67 (1), 29-50.

FAO. (2000). Global Forest Resources Assessment 2000 - Main Report. FAO Forestry Paper 140. UN Food and Agriculture Organization, Rome.

Feranec, J., Jaffrain, G., Soukup, T., \& Hazeu, G. (2010) Determining changes and flows in European landscapes 1990-2000 using CORINE land cover data. Applied Geography, 30 (1), 19-35.

Fischer, J., Zerger, A., Gibbons, P., Stott, J., \& Law, B. S. (2010). Tree decline and the future of Australian farmland biodiversity. Proceedings of the National Academy of Sciences of the United States of America, 107 (45), 19597-19602.

Freemark, K. E., Boutin, C., \& Keddy, C. J. (2002). Importance of farmland habitats for conservation of plant species. Conservation Biology, 16 (2), 399-412.

Geri, F., Amici, V., \& Rocchini, D. (2010). Human activity impact on the heterogeneity of a Mediterranean landscape. Applied Geography, 30 (3), 370-379.

Gillanders, S. N., Coops, N. C., Wulder, M. A., Gergel, S. E., \& Nelson, T. (2008). Multitemporal remote sensing of landscape dynamics and pattern change: describing natural and anthropogenic trends. Progress in Physical Geography, 32 (5), 503-528. 
Grashof-Bokdam, C. J., Chardon, J. P., Vos, C. C., Foppen, R. P. B., WallisDeVries, M., van der Veen, M., \& Meeuwsen, H. A. M. (2009). The synergistic effect of combining woodlands and green veining for biodiversity. Landscape Ecology, 24 (8), 1105-1121.

Haines-Young, R., \& Chopping, M. (1996). Quantifying landscape structure: A review of landscape indices and their application to forested landscapes. Progress in Physical Geography, 20 (4), 418-445.

Hampicke, U. (2006). Efficient conservation in Europe's agricultural countryside - rationale, methods and policy reorientation. Outlook on Agriculture, 35 (2), 97-105.

Herzog, F. (1998). Streuobst: a traditional agroforestry system as a model for agroforestry development in temperate Europe. Agroforestry Systems, 42 (1), 61-80.

Hinsley, S. A., \& Bellamy, P. E. (2000). The influence of hedge structure, management and landscape context on the value of hedgerows to birds: A review. Journal of Environmental Management, 60 (1), 33-49.

Jim, C. Y., \& Chen, W. Y. (2009). Diversity and distribution of landscape trees in the compact Asian city of Taipei. Applied Geography, 29 (4), 577-587.

Jones, N., de Graaff, J., Rodrigo, I., \& Duarte, F. (2011). Historical review of land use changes in Portugal (before and after EU integration in 1986) and their implications for land degradation and conservation, with a focus on Centro and Alentejo regions. Applied Geography, 31 (3), 1036-1048.

Käyhkö, N., Fågerholm, N., Asseid, B. S., \& Mzee, A. J. (2011). Dynamic land use and land cover changes and their effect on forest resources in a coastal village of Matemwe, Zanzibar, Tanzania. Land Use Policy, 28 (1), 26-37.

Kristensen, S. P., \& Caspersen, O. H. (2002). Analysis of changes in a shelterbelt network landscape in central Jutland, Denmark. Journal of Environmental Management, 66 (2), 171-183.

Kuussaari, M., Bommarco, R., Heikkinen, R. K., Helm, A., Krauss, J., Lindborg, R., Ockinger, E., Partel, M., Pino, J., Roda, F., Stefanescu, C., Teder, T., Zobel, M., \& Steffan-Dewenter, I. (2009). Extinction debt: a challenge for biodiversity conservation. Trends in Ecology \& Evolution, 24 (10), 564-571.

LVA Baden-Württemberg. (1993). 175 Jahre Württembergische Landesvermessung. Landesvermessungsamt Baden-Württemberg, Stuttgart.

Mailänder, S. (2005). Rekonstruktion der Landnutzungsänderungen im Bereich des "Kalten Feldes" (Schwäbische Ostalb) seit Beginn des 19. Jahrhunderts - ein Beitrag zur Pflege- und Entwicklungsplanung. Naturschutz Landschaftspflege BadenWürttemberg, 75, 77-112.

Manning, A. D., Fischer, J., \& Lindenmayer, D. B. (2006). Scattered trees are keystone structures - Implications for conservation. Biological Conservation, 132 (3), 311-321.

Mather, A. S., Hill, G., \& Nijnik, M. (2006). Post-productivism and rural land use: cul de sac or challenge for theoretization? Journal of Rural Studies, 22 (4), 441-455.

MLR. (2009). Streuobstwiesen in Baden-Württemberg. Daten, Handlungsfelder, Maßnahmen, Förderung. Ministerium für Ernährung und Ländlichen Raum Baden-Württemberg, Stuttgart.

Ostapowicz, K., Vogt, P., Riitters, K. H., Kozak, J., \& Estreguil, C. (2008). Impact of scale on morphological spatial pattern of forest. Landscape Ecology, 23 (9), 1107-1117. 
Persson, A. S., Olsson, O., Rundlof, M., \& Smith, H. G. (2010). Land use intensity and landscape complexity-Analysis of landscape characteristics in an agricultural region in Southern Sweden. Agriculture Ecosystems \& Environment, 136 (1-2), 169-176.

Petit, S., Stuart, R. C., Gillespie, M. K., \& Barr, C. J. (2003). Field boundaries in Great Britain: stock and change between 1984, 1990 and 1998. Journal of Environmental Management, 67 (3), 229-238.

Plieninger, T. (2011). Capitalizing on the carbon sequestration potential of agroforestry in Germany's agricultural landscapes: Realigning the climate-change mitigation and landscape conservation agendas. Landscape Research, DOI: 10.1080/01426397.2011.582943.

Plieninger, T., Rolo, V., \& Moreno, G. (2010). Large-scale patterns of Quercus ilex, Quercus suber, and Quercus pyrenaica regeneration in Central-Western Spain. Ecosystems, 13 (5), 644-660.

Plieninger, T., \& Schaar, M. (2008). Modification of land cover in a traditional agroforestry system in Spain: Processes of tree expansion and regression. Ecology and Society, 13 (2), 25, http://www.ecologyandsociety.org/vol13/iss2/art25.

Pontius, R. G., Shusas, E., \& McEachern, M. (2004). Detecting important categorical land changes while accounting for persistence. Agriculture Ecosystems \& Environment, $101(2-3), 251-268$.

Poschlod, P., \& WallisDeVries, M. F. (2002). The historical and socioeconomic perspective of calcareous grasslands - lessons from the distant and recent past. Biological Conservation, 104 (3), 361-376.

Ressel, R., \& Zimmerer, J. (1989). Landschaftsveränderungen auf der Schwäbischen Alb am Beispiel der Gemarkungen Ehestetten, Aichelau und Aichstetten (Lkr. Reutlingen). Veröffentlichungen Naturschutz Landschaftspflege Baden-Württemberg, 64/65, 81128.

Schleyer, C., \& Plieninger, T. (2011). Obstacles and options for the design and implementation of payment schemes for ecosystem services provided through farm trees in the German state of Saxony. Environmental Conservation, DOI: 10.1017/S0376892911000361.

Schneeberger, N., Bürgi, M., \& Kienast, F. (2007). Rates of landscape change at the northern fringe of the Swiss Alps: Historical and recent tendencies. Landscape and Urban Planning, 80 (1-2), 127-136.

Sheeren, D., Bastin, N., Ouin, A., Ladet, S., Balent, G., \& Lacombe, J. P. (2009). Discriminating small wooded elements in rural landscape from aerial photography: a hybrid pixel/object-based analysis approach. International Journal of Remote Sensing, 30 (19), 4979-4990.

Siren, A. H., \& Brondizio, E. S. (2009). Detecting subtle land use change in tropical forests. Applied Geography, 29 (2), 201-211.

Skaloš, J., \& Engstová, B. (2010). Methodology for mapping non-forest wood elements using historic cadastral maps and aerial photographs as a basis for management. Journal of Environmental Management, 91 (4), 831-843.

Skaloš, J., Weber, M., Lipský, Z., Trpáková, I., Šantrůčková, M., Uhlířová, L., \& Kukla, P. (2011). Using old military survey maps and orthophotograph maps to analyse long- 
term land cover changes - Case study (Czech Republic). Applied Geography, 31 (2), 426-438.

Sklenicka, P., Molnarova, K., Brabec, E., Kumble, P., Pittnerova, B., Pixova, K., \& Salek, M. (2009). Remnants of medieval field patterns in the Czech Republic: Analysis of driving forces behind their disappearance with special attention to the role of hedgerows. Agriculture Ecosystems \& Environment, 129 (4), 465-473.

StLA. (2011). Struktur- und Regionaldatenbank. Statistisches Landesamt BadenWürttemberg, Stuttgart. Retrieved April 20, 2011 from:http://www.statistik.badenwuerttemberg.de/SRDB/.

van Doorn, A. M., \& Pinto Correia, T. (2007). Differences in land cover interpretation in landscapes rich in cover gradients: reflections based on the montado of South Portugal. Agroforestry Systems, 70 (2), 169-183.

von Schnakenburg, P., \& Schmieder, K. (2007). Anwendung von Landschaftsmaßen zur Analyse des Landschaftswandels am Beispiel des Raichberges (Schw. Alb). Berichte des Instituts für Landschafts- und Pflanzenökologie der Universität Hohenheim, 17, 205-220.

Vos, W., \& Klijn, J. (2000). Trends in European landscape development: prospects for a sustainable future. In J. A. Klijn \& W. Vos (Eds.), From Landscape Ecology to Landscape Science (pp. 3-29). Kluwer Academic Publishers, Dordrecht.

Vuorela, N., Alho, P., \& Kalliola, R. (2002). Systematic assessment of maps as source information in landscape-change research. Landscape Research, 27 (2), 141-166.

Weller, F. (1996). Streuobstwiesen. Herkunft, heutige Bedeutung und Möglichkeiten der Erhaltung. In W. Konold (Ed.), Naturlandschaft - Kulturlandschaft. Die Veränderung der Landschaften nach der Nutzbarmachung durch den Menschen (pp. 137-160). Ecomed, Landsberg. 


\section{Tables}

Table 1

Correlation of number of scattered tree plots and length of alleys/tree rows with land cover classes for the plateau area (Spearman's r, ${ }^{*} \mathrm{p}<0.01,{ }^{* *} \mathrm{p}<0.01,{ }^{* * *} \mathrm{p}<0.001, \mathrm{n}=10$ ).

\begin{tabular}{lcc}
\hline & $\begin{array}{r}\text { Plots with } \\
\text { scattered } \\
\text { trees (n) }\end{array}$ & $\begin{array}{r}\text { Alleys/ } \\
\text { tree rows } \\
(\mathrm{km})\end{array}$ \\
\hline Forest (ha) & $-0.697^{*}$ & $-0.952^{* * *}$ \\
Urban (ha) & $-0.661^{*}$ & $-0.891^{* *}$ \\
Cropland (ha) & 0.091 & $0.321^{* * *}$ \\
Wasteland (ha) & $0.685^{*}$ & $0.964^{*}$ \\
Grassland (ha) & $0.733^{*}$ & $0.648^{*}$ \\
\hline
\end{tabular}

\section{Table 2}

Percentage of observed landscape changes in plots with lost and persistent scattered trees in the plateau area, 1901-2009 (n.s. = not significant).

\begin{tabular}{lrrr}
\hline & $\begin{array}{c}\text { Lost } \\
(\mathrm{n}=235)\end{array}$ & $\begin{array}{r}\text { Persistent } \\
(\mathrm{n}=56)\end{array}$ & \multicolumn{1}{c}{$\mathrm{p}$} \\
\hline Change of grassland cover $\left(\mathrm{m}^{2}\right)$ & $-16.4 \%$ & $-3.3 \%$ & 0.010 \\
Change of wasteland cover $\left(\mathrm{m}^{2}\right)$ & $-9.2 \%$ & $-5.2 \%$ & n.s. \\
Change of cropland cover $\left(\mathrm{m}^{2}\right)$ & $-5.7 \%$ & $-3.3 \%$ & n.s. \\
Change of forest cover $\left(\mathrm{m}^{2}\right)$ & $18.0 \%$ & $5.1 \%$ & 0.015 \\
Change of built-up land cover $\left(\mathrm{m}^{2}\right)$ & $11.9 \%$ & $6.2 \%$ & 0.027 \\
\hline
\end{tabular}

Table 3

Spatial pattern of orchards in the foothill area (1905-2009).

\begin{tabular}{lrrrrrrrr}
\hline & 1905 & 1930 & 1955 & 1967 & 1979 & 1989 & 1998 & 2009 \\
\hline Core (ha) & 226.9 & 258.4 & 255.4 & 305.3 & 284.8 & 319.8 & 310.3 & 321.9 \\
Islet (ha) & 0.8 & 0.4 & 0.4 & 0.0 & 0.3 & 0.0 & 0.0 & 0.0 \\
Perforation (ha) & 9.2 & 9.4 & 9.3 & 12.1 & 10.0 & 9.7 & 9.9 & 9.1 \\
Edge (ha) & 59.6 & 56.7 & 56.7 & 43.2 & 43.4 & 28.6 & 28.7 & 27.8 \\
Loop (ha) & 3.3 & 3.0 & 2.7 & 1.1 & 0.8 & 0.1 & 0.0 & 0.0 \\
Bridge (ha) & 2.4 & 2.1 & 1.3 & 0.5 & 0.5 & 0.1 & 0.2 & 0.1 \\
Branch (ha) & 8.1 & 5.7 & 6.6 & 5.0 & 4.8 & 1.6 & 1.9 & 1.2 \\
\hline
\end{tabular}


Table 4

Systematic gains and losses of orchards in percent of the landscape, 1905-2009.

\begin{tabular}{llll}
\hline $\begin{array}{l}\text { Gains to } \\
\text { orchards from }\end{array}$ & $\begin{array}{l}\text { Observed } \\
\text { change }\end{array}$ & $\begin{array}{l}\text { Expected } \\
\text { change }\end{array}$ & $\begin{array}{l}\text { Difference between } \\
\text { observed and } \\
\text { expected change }\end{array}$ \\
\hline Forest & 0.17 & 4.49 & -4.32 \\
Urban & 0.18 & 0.73 & -0.55 \\
Cropland & 6.80 & 3.96 & 2.84 \\
Wasteland & 1.67 & 1.43 & 0.24 \\
Grassland & 0.02 & 0.40 & -0.38 \\
Vineyard / Hops & 2.65 & 0.47 & 2.18 \\
\hline & & & \\
\hline Losses of & Observed & Expected & Difference between \\
orchards to & change & change & ebserved and \\
& & & expected change \\
\hline $\begin{array}{l}\text { Forest } \\
\text { Urban }\end{array}$ & 0.89 & 0.21 & 0.68 \\
Cropland & 4.41 & 0.11 & 4.31 \\
Wasteland & 1.10 & 5.31 & -4.21 \\
Grassland & 0.10 & 2.00 & -1.89 \\
Vineyard / Hops & 0.63 & 0.57 & 0.05 \\
\hline
\end{tabular}

Table 5: Relative adjacency index for orchards.

\begin{tabular}{lrrrr}
\hline & 1905 & & 2009 & \\
\cline { 2 - 5 } & $\mathrm{km}$ & $\%$ & $\mathrm{~km}$ & $\%$ \\
\hline Cropland & 56.5 & 64.7 & 13.9 & 36.3 \\
Forest & 10.9 & 12.5 & 13.8 & 36.0 \\
Urban & 3.8 & 4.4 & 7.8 & 20.3 \\
Wasteland & 6.6 & 7.6 & 2.8 & 7.4 \\
Vineyard / Hops & 9.5 & 10.8 & 0.0 & 0.0 \\
Total & 87.3 & 100.0 & 38.4 & 100.0 \\
\hline
\end{tabular}




\section{Figures}

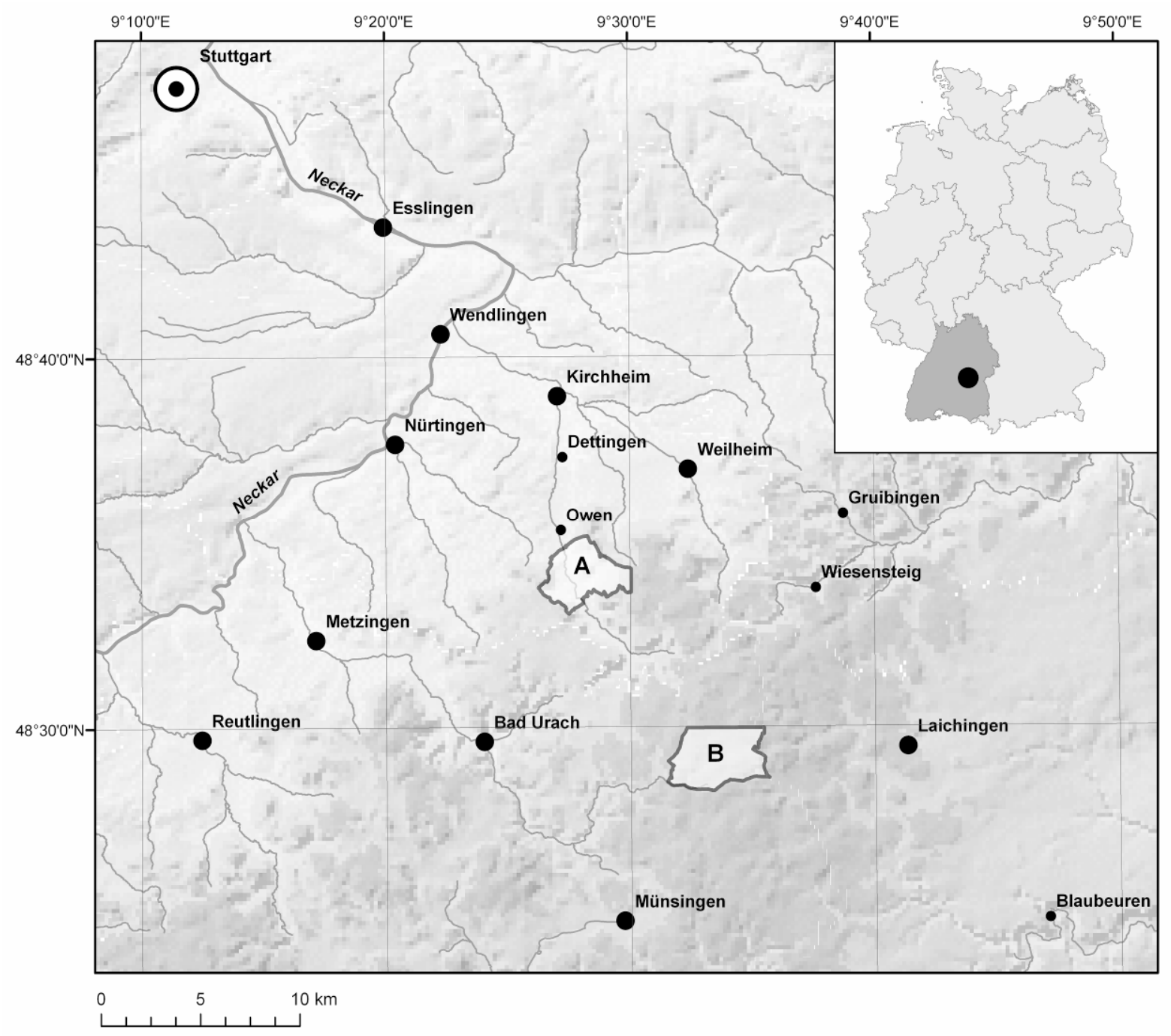

Fig. 1. Location of the Unterlenningen (foothills, A) and Zainingen (plateau, B) areas in the Swabian Alb mountain range of Southern Germany. 

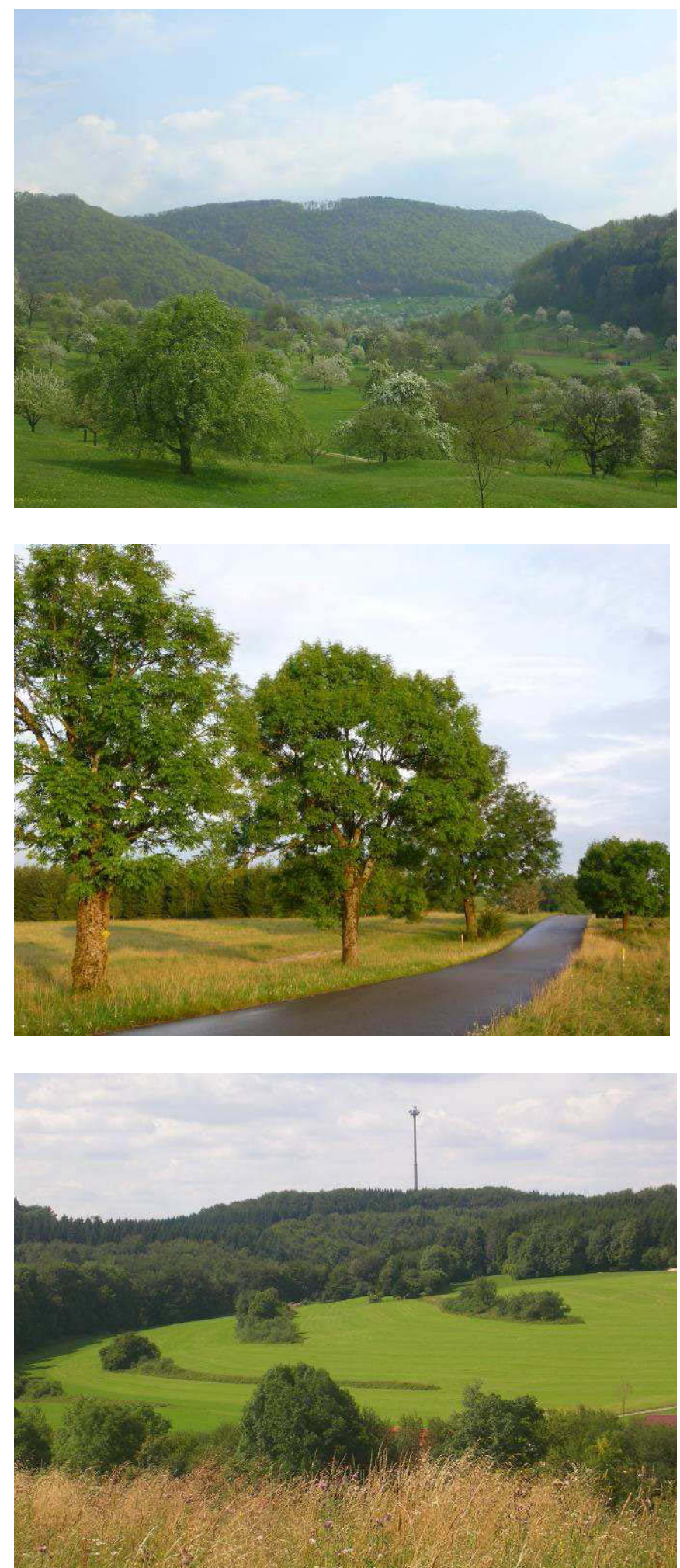

Fig. 2. Examples of a) an orchard in the foothill area, b) an alley and c) hedgerows in the plateau area. 


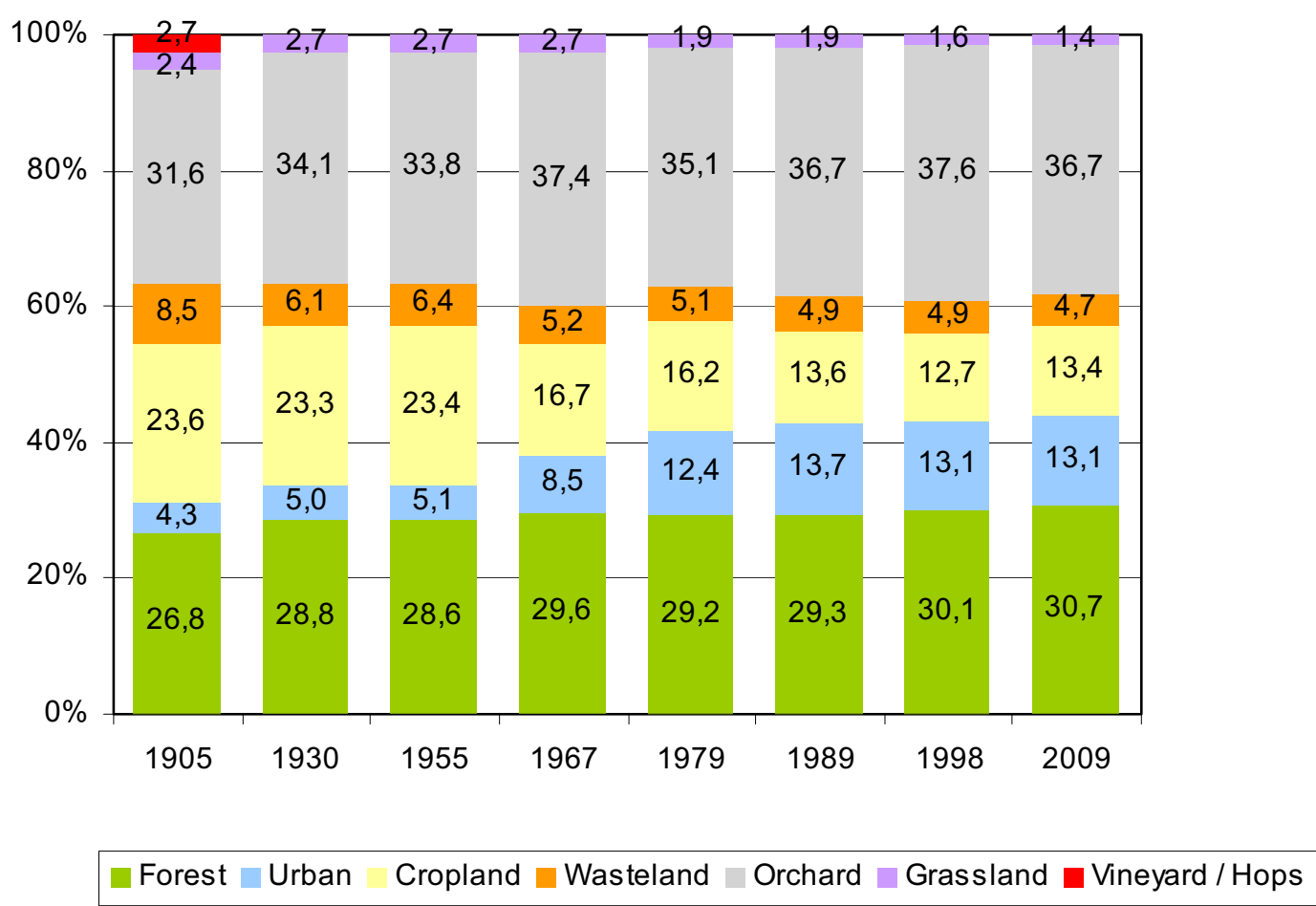

Fig. 3. Area of land cover classes in percent of landscape total for the foothill area. 


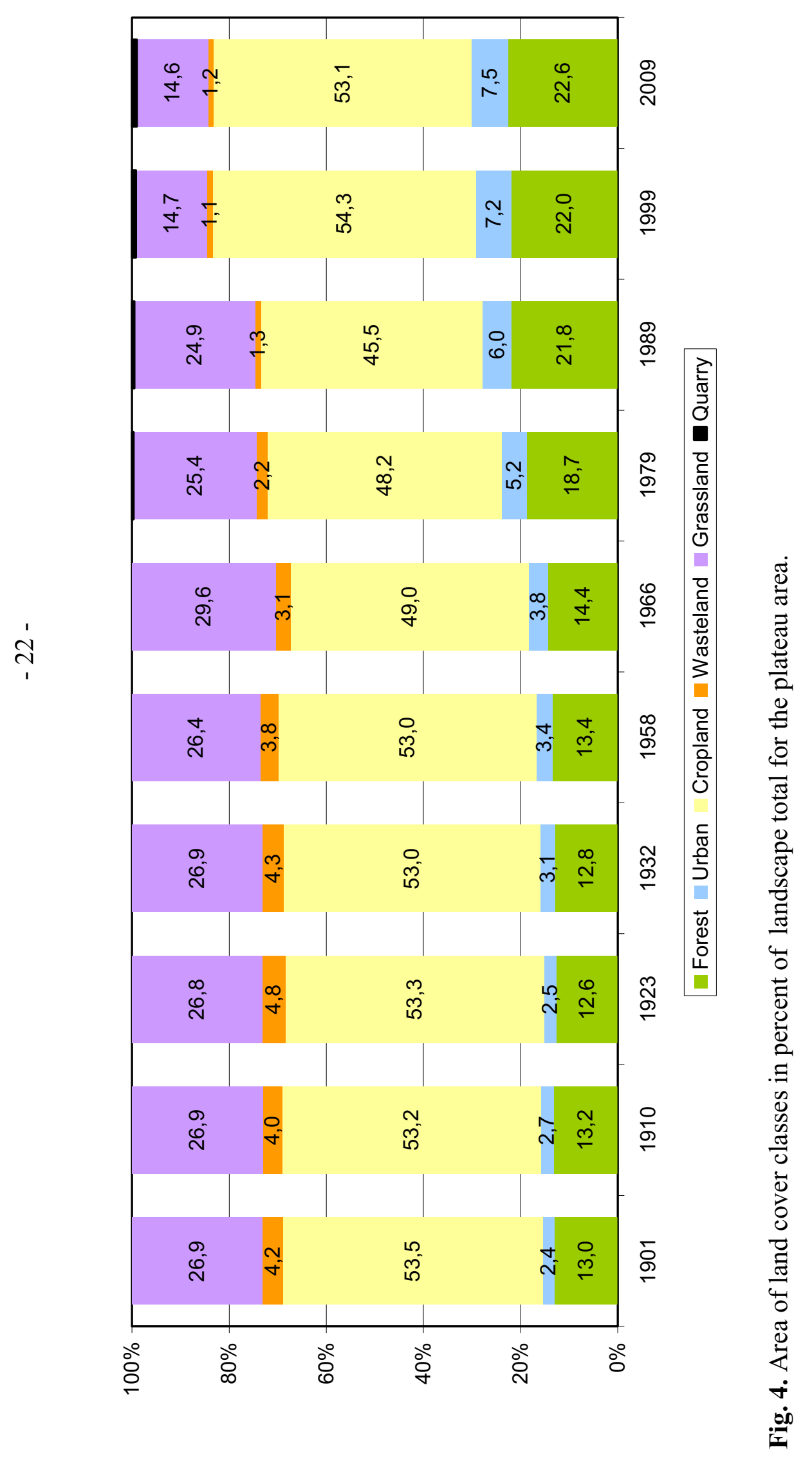



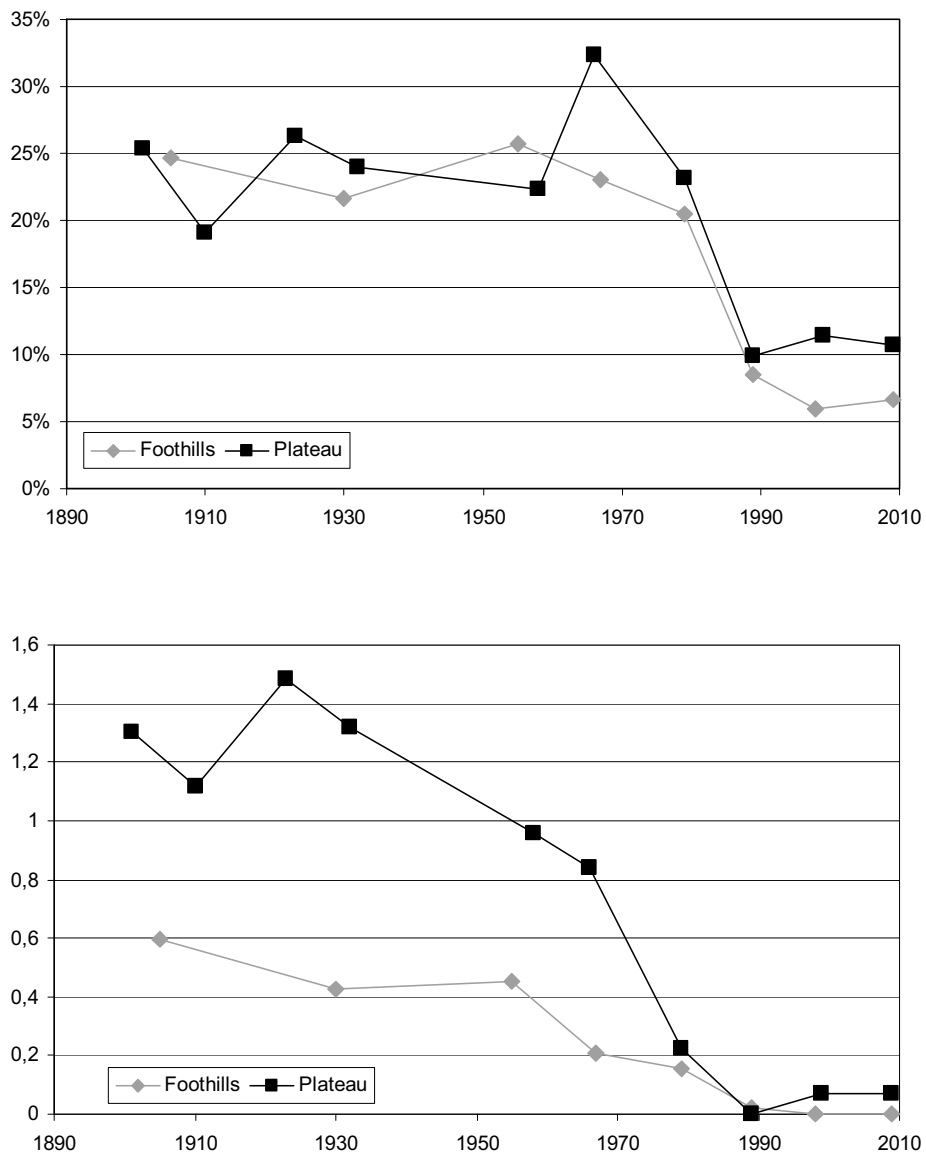

Fig. 5. Counting of individual trees from 1901 to 2009 in a) percentage of cells with presence of scattered trees and b) lengths of alleys and tree rows in $\mathrm{km}$ per $\mathrm{km}^{2}$. 


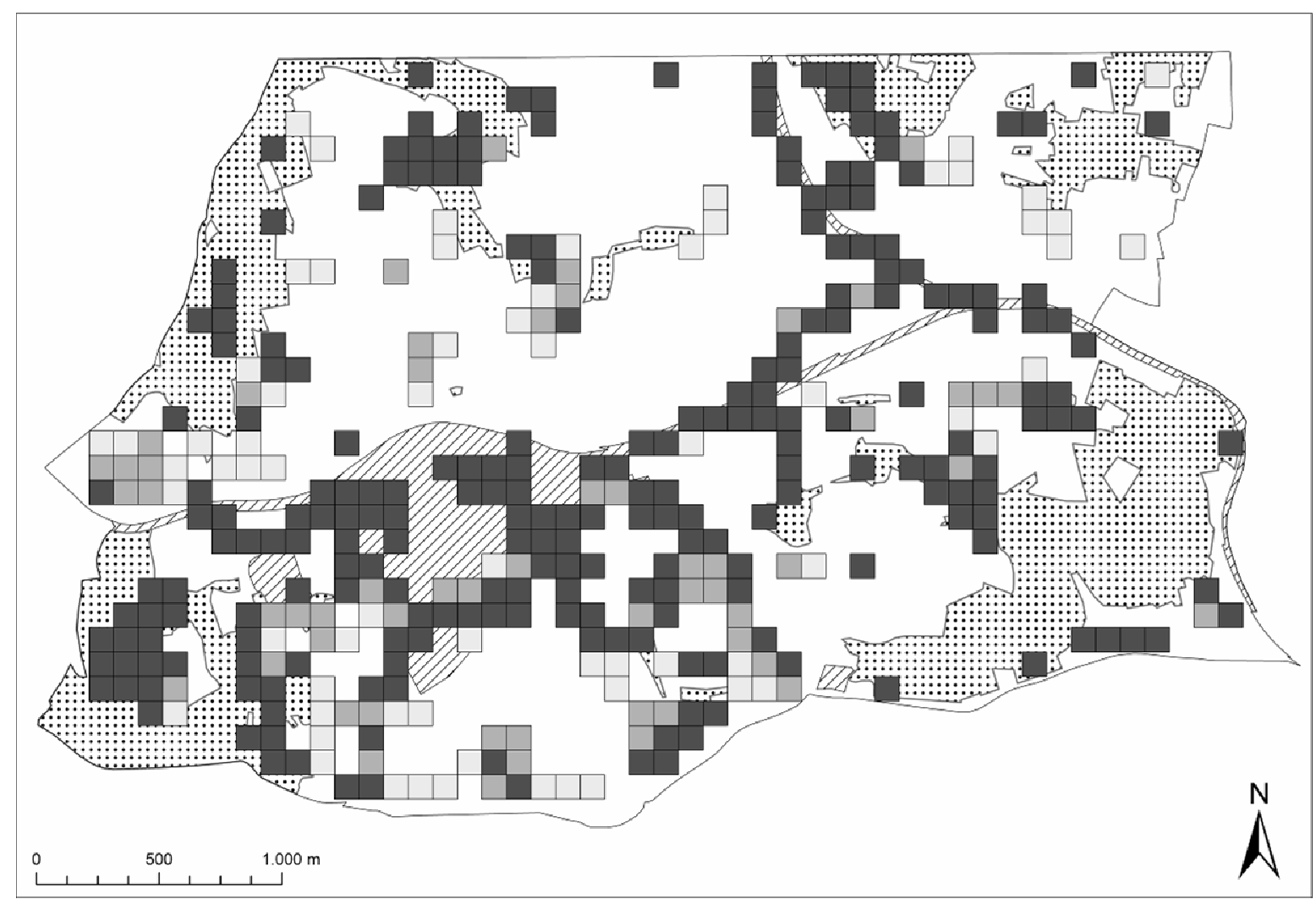

Fig. 6. Distinct trajectory classes of 1 ha plots with scattered trees, exhibiting areas of tree persistence (grey), loss (dark grey), and gain (light grey) in the plateau area between 1901 and 2009. Plots with lost trees were mainly covered by closed forest (dotted areas) and built-up land (shaded areas) in 2009. 


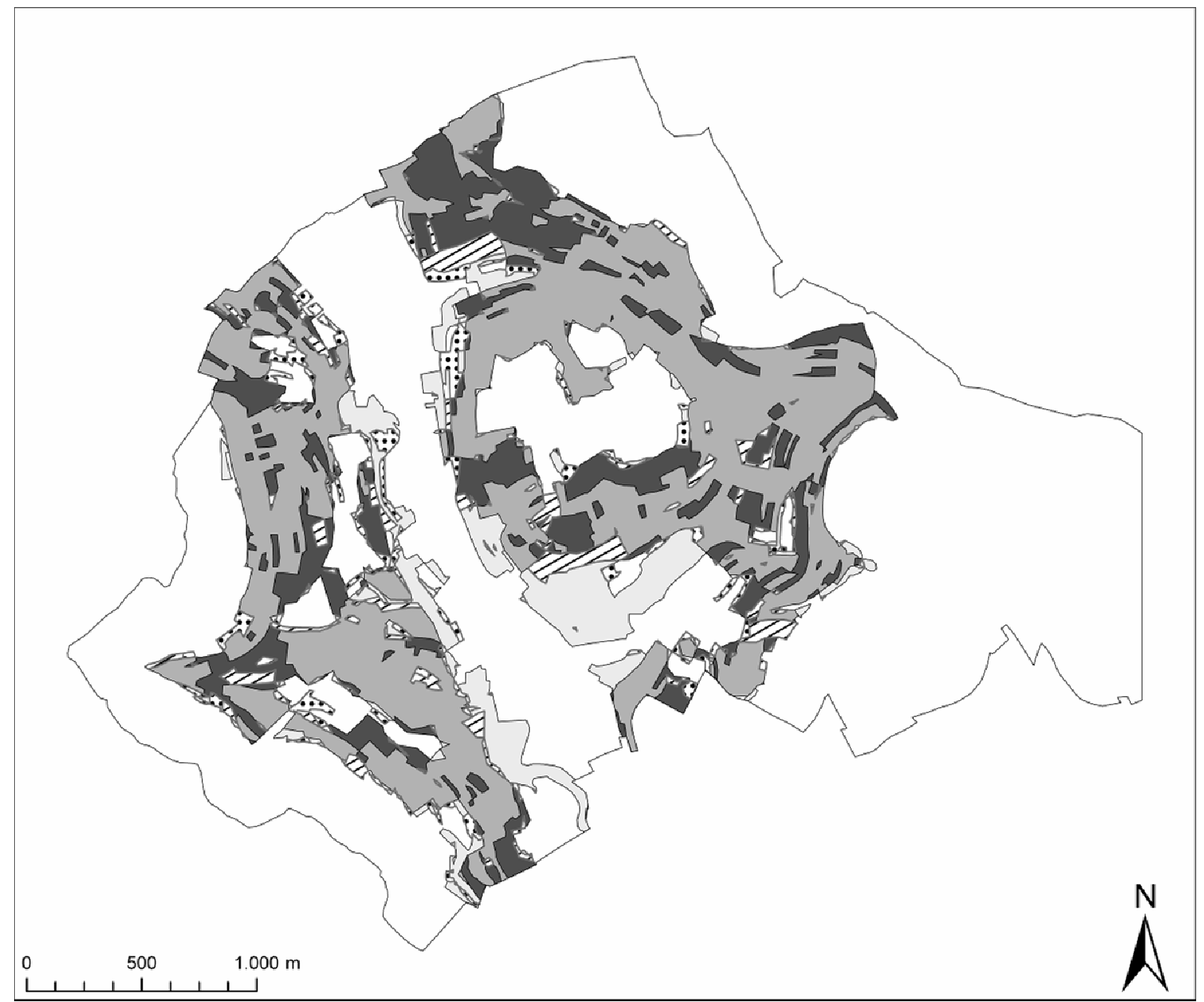

Fig. 7. Observed trajectories of orchard change in the foothill area, exhibiting areas of persistence (grey), decrease (dark grey), increase (light grey) and turnover without (dotted) and with orchard (shaded) in 2009. 